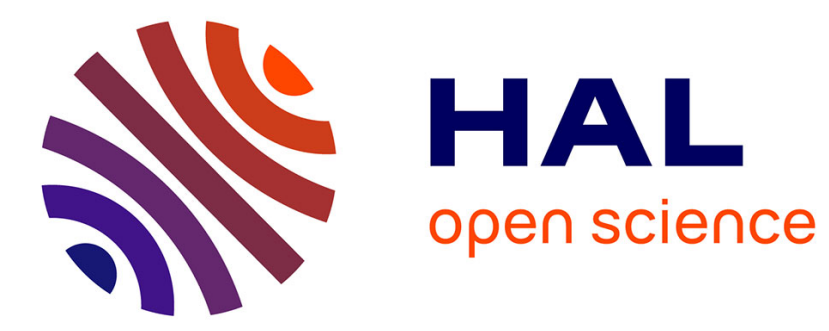

\title{
Mobbing in a cross-sectional national sample: The Turkish Case
}

Jale Minibas-Poussard, Meltem İdiğ-Çamuroğlu

\section{To cite this version:}

Jale Minibas-Poussard, Meltem İdiğ-Çamuroğlu. Mobbing in a cross-sectional national sample: The Turkish Case. Australian Journal of Business and Management Research, 2016. hal-01615570

\author{
HAL Id: hal-01615570 \\ https://hal.science/hal-01615570
}

Submitted on 12 Oct 2017

HAL is a multi-disciplinary open access archive for the deposit and dissemination of scientific research documents, whether they are published or not. The documents may come from teaching and research institutions in France or abroad, or from public or private research centers.
L'archive ouverte pluridisciplinaire HAL, est destinée au dépôt et à la diffusion de documents scientifiques de niveau recherche, publiés ou non, émanant des établissements d'enseignement et de recherche français ou étrangers, des laboratoires publics ou privés. 


\title{
MOBBING IN A CROSS-SECTIONAL NATIONAL SAMPLE: The Turkish Case
}

\author{
Jale Minibas-Poussard, PhD and Meltem İdiğ-Çamuroğlu, PhD*
}

\begin{abstract}
In this empirical study we examined mobbing settings and outcomes with a data set from a cross-sectional occupational sample collected in ten cities in Turkey $(N=853)$. The prevalence of mobbing in this sample was $23 \%$, while victimization was $17 \%$ only. The most frequent aggressive behaviors were threats to the victim's personal and occupational reputation such as having been denied a praise or promotion, having had one's contributions ignored by others, having been given unreasonable workloads above competence or simple and meaningless work below competence. Perpetrators were mostly superiors. Analyses revealed that oppressive management was the most influential factor for mobbing in work environment.
\end{abstract}

Keywords: Mobbing, Individual Behavior, Organizational Behavior

JEL Classification: C91, C92, D22

\section{INTRODUCTION}

The term mobbing word was first used by the ethologist Konrad Lorenz to describe aggressive animal gang behavior (Dermaret, 1979). In the 70s, the physician Peter Heinemann used this term in his work analyzing the hostile behaviors of a group of children toward one single child. In the 90s, Leymann borrowed the term to describe similar workplace behaviors and initiated a trend of research on the phenomenon (Leymann, 1996a). Mobbing in organizations can be defined as a form of psychological harassment which has severe consequences for the target person. Leymann (1996a) defined mobbing as a type of conflict in which victims are subjected to a stigmatization process and the encroachment of their civil rights. According to Leymann, this must occur at least once a week and over a period of at least six months. This traumatizing experience may lead to the individual's complete withdrawal from the labor market, as victims may end up unable to face work.

While Leymann preferred the phrase mobbing, some other researchers use the term bullying which has also been widely accepted almost all over the literature. Besides these words, to express the violence in the workplace several terms are used by different researchers such as; harassment (Brodsky, 1976), workplace trauma (Wilson, 1991), emotional abuse (Keashly, 1998), workplace aggression (Neuman and Baron, 1998), victimization (Aquino Grover, Bradfield \& Allen, 1999) and incivility (Cortina Magley, Williams \& Langhout, 2001). All these terms refer to the same phenomenon.

A widely used definition of bullying is given by Einarsen (1999): Bullying emerges when one or several individuals persistently over a period of time perceive themselves to be on the receiving end of negative actions from one or several persons, in a situation where the target/s of bullying has difficulty in defending him/herself against these actions.

There are numerous definitions to list, however they have several common characteristics such as; aggressive behavior, repetition, duration in time and lack of power balance:

- A hostile and destructive aim is prominent in mobbing. While Leymann (1996b) applies the criterion of one aggressive behavior to diagnose mobbing, other researchers (Mikkelsen \& Einarsen, 2001; Salin, 2001; Lutgen-Sandvik, Tracy \& Alberts, 2007) apply the criterion of at least two hostile behaviors occurring.

- In order to constitute a destructive process, these behaviors must occur more than once, and as just mentioned, some researchers do not accept one single aggressive behavior as mobbing (Lutgen-Sandvik et al., 2007). For Leymann (1996a), repetition or frequency of aggressive behaviors must be at least once a week.

- About the duration in time, researchers generally agree on at least six months (Hoel, Cooper \& Faragher, 2001; Leymann, 1996b; Mikkelsen \& Einarsen, 2001; Zapf, Knorz \& Kulla, 1996).

\footnotetext{
* The authors are respectively Professor at Galatasaray University, Business Administration Department Istanbul and Psychotherapist, at BILTED Psychotherapy Clinic Ankara Turkey Corresponding author email: meltem@biltedpdm.com and meltemcamur@gmail.com
} 
- Inequality of power between the parties plays an essential role in definition of mobbing (Einarsen $\&$ Mikkelsen, 2003). This lack of equality exists either at the beginning or during the process (Lutgen-Sandvik et al., 2007).

Leymann (1996a) classified the types of mobbing into five categories of threats to:

- Victim's communication (e.g. silent treatment, interrupted when speaking, not been listened to)

- Victim's maintaining social contacts (e.g. being isolated in a room from others, not being talked to),

- Victim's personal reputation (e.g. been subjected to rumors),

- Victim's occupational reputation (e.g. not being given any work tasks, been blamed for other people's mistakes) and

- Victim's physical health (e.g. been given dangerous work tasks, been threatened with physical harm or been physically harmed, been sexually assaulted).

Based on Buss's (1961) aggressive behaviors classification, Baron and Neuman (1996) clarified the workplace aggressive behaviors. For example; failing to deny false rumors about target (verbal/passive/indirect) or spreading false rumors about target (verbal/active/indirect) etc. Active/passive and direct/indirect dichotomies play an important role in diagnosing since passive and indirect behaviors might be ignored or might even not be identified as aggressive behaviors. Based on Bjorkqvist, Osterman \& Lagerspetz (1994) study, Baron, Neuman and Geddes (1999) further elaborated aggressive behaviors as covert and overt; covert ones are verbal, passive and indirect. On the other hand, overt behaviors are physical, active and direct. Baron et al. (1999) concluded that covert aggressive behaviors are more frequently encountered in the workplaces.

In a recent study, Einarsen, Hoel and Notelaers (2009), divided the aggressive behaviors into three groups in the instrument they designed to measure exposure to mobbing: a) work-related bullying (being given tasks with unreasonable deadlines), b) person-related bullying (having allegations made against you) and c) physically intimidating bullying (intimidating behaviors such as finger-pointing, invasion of personal space, shoving, blocking your way).

\section{LITERATURE REVIEW \\ Causes of Mobbing}

The mobbing process is a vicious cycle and in order to grasp it in its entirety, it is necessary to determine the interacting factors and the relationships drawn between them. Zapf (1999) also emphasized the limitations of linear thinking in explaining the reasons of mobbing. In reality, the cause-effect relationship is not straightforward and simultaneous effects originate toward many directions. For instance, organizational policies and rules may provide fertile grounds for mobbing, the manager may be indifferent to an existing conflict, mobbing may lead to irritability and hostile behaviors in the victim, the victim may annoy other colleagues and lose group social support, and so on.

Recently, the ecological model (Johnson, 2011) have been used widely to explain the occurrence of mobbing which was built on Bronfenbrenner's (1979) ecology of human development model. This theory states that human development is shaped by factors in a nested layer of hierarchical systems. Accordingly, the ecological model of workplace bullying consists four interrelated systems: microsystem (perpetrator and target) the mesosystem (workgroup and manager), the exosystem (organization), and the macrosystem (society). The model is also divided into three stages: antecedents, bullying event itself, and impacts/outcomes. While antecedents of mobbing can be found in these four systems, it has different impacts or outcomes on the same systems as well.

Zapf and Einarsen (2003) underlined two reasons of aggression in terms of mobbing: personal retaliation to protect self-esteem and lack of social competencies. Self-esteem can be defined a favorable global evaluation of oneself. Protection or enhancement of self-esteem is a basic human motive which influences and regulates behaviors in social situations. Thus, social interactions are uncomplicated as long as both parties feel respected and recognized, in other words, if self-evaluation and external evaluation are congruent. Conflicts and mobbing arise when this is not the case. In other mobbing cases, lack of social competencies is the dominating factor in the situation. Difficulties in emotional control may lead a manager to scolding subordinates in demeaning ways. Not being able to reflect on the consequences of one's own behavior may also cause mobbing. Sometimes, because of poor communication between perpetrator and victim, bullies never become fully aware of the results of their own behavior. 
With an individualistic perspective, some researchers focused on perpetrators' psychopathological features. Hirigoyen (2001) claimed that perpetrators had narcissistic characteristics and they do not trust in people around them. Their relationships are based on gathering power and manipulations. Narcissistic people believe that they need to be aggressive to gain power and simply to exist. Perpetrators with narcissistic personality disorder feel like they have to control people who scare them. When there is no threatening people around, they think they can live in an imaginary safe world in an omnipotent position (Wyatt and Hare, 1997). Mathieu et al. (2013) stated that psychopathic traits was the most important reason for abnormal manager behaviors which create enormous distress on employees. These traits can be listed as grandiosity, self-centeredness, superficial emotions, irresponsibility, lack of empathy and regret and ignoring social norms or opposing them.

In addition to the victims' personality traits, group norms in organizations are an important factor that possibly determine the mobbing process. Norms govern all group behavior, including antisocial and aggressive behavior, while they also regulate the means of denial of the existence of such behavior and the kinds of excuses and rationalizations used to justify it (Wyatt \& Hare, 1997). Any organization combining rules of aggressive behaviors and denial is fertile ground for mobbing phenomena. Also, the silence of witnesses is a critical element to the success of the perpetrator. In some cases, witnesses may be silent because they are not fully aware of what is going on, or may take a long time to realize what is going on. In other cases, witnesses may keep silent even after they realize that mobbing is taking place, but still do not want to take responsibility (Debout \& Larose, 2003). If silent witnesses are managers, the case becomes more serious, as denial mechanisms and lack of managers' interference empower the aggressor (Einarsen, Raknes \& Matthiesen, 1994).

To be able to sustain competition in a global market, organizations are forced to technological and structural transformation. Decreased dividends and instability of the market, reorganizations and shrinking in the companies cause strained processes. As a result; workers in organizations at all levels are challenged with overloaded tasks and insecurity. Baron and Neuman (1998), stated that four types of change can create aggression in organizations. These are (a) decrease in payments because of restricted costs, (b) changes in the structure of organization, (c) decline in job security and (d) social changes in job environment. Throughout the changing, while personnel struggling with feelings of loss and stress, senior managers can create instability and show aggressive behavior due to their fear of losing control. Leyman (1996a) points out senior managers' conflict; although they have information about new applications, they lack the skills of implementation of them.

Leymann (1996a), indicated qualitative and quantitative aspects of overloaded tasks. Quantitative aspect is fast rhythm; obligation of completing a lot in a very short time. On the other hand, qualitative aspect is losing the meaning of job which makes the load even heavier.

Künzi,Vicario, Künzi and Jeandet (2006) listed three psychosocial factors which impair the work environment and set up grounds for mobbing: (i) excessive work loads, (ii) over-responsibility, and (iii) getting the deserved appreciation. Lack of recognition and appreciation is a major stress source at work places (Legeron, 2000). Einarsen et al. (1994) determined a stressful workplace as a crucial factor in mobbing, since stress induces interpersonal problems. Zapf (1999) on the other hand, underlined that time pressure related to excessive workloads is a ground for interpersonal conflicts which then leads to mobbing.

Organizational structure also affects management style and employee relationships. Kernberg (2002) underlined the relationship between the size of organizations, aggressiveness and managers' mobbing behavior. In smallsized and independent companies, managers are in direct relationship with each employee, and social control nets prevent aggressive behaviors. On the contrary, in organizations with four to seven hierarchical levels, it is impossible to develop wide and strong interpersonal relations and mobbing becomes easier. Some organizations aim to develop relationships of equity among members and actively decrease the number of hierarchial levels, but still, ambitious employees who expect to be promoted would tend to irritate others (Spindel, 2008). Hofsteade and Bollinger (1987) stated that matrix organizations are powerful in cultures which support team work. On the contrary, in hierarchical cultures matrix organizations and company politics clash and create prolific grounds for mobbing. Finally, obligatory cooperation in work teams may put heavy pressure on employees and lead to mobbing as well (Zapf et al., 1996).

Some other researchers have suggested different organizational reasons for mobbing; competitive cultures (Vartia, 1996; O’Moore, Seigne, McGuire \& Smith, 1998; Rayner et al., 2002), and strictly work oriented management combined with an oppressive controlling (Hauge, Skogstad \& Einarsen., 2007). Nevertheless, it is challenging to determine the cause-effect relationship between mobbing, organizational structure and/or management style. Regardless of management styles and structures, humanistic perspectives and aggressive communication bring about conflicts and prepares atmosphere for mobbing. 


\section{Outcomes of Mobbing}

Work is a means for self-realization. In general, victims of mobbing report less job satisfaction due to decreased work performance. Once victims lose confidence about their own abilities, their social abilities are also affected; and an important part of the self is affected (Bréard \& Pastor, 2002). Many researchers (Leymann \& Gustafsson, 1996; Hoel \& Cooper, 2001, Kivimaki, Elovainio \& Vahtera, 2000; Gillow, Hopkins, \& Williams, 2003; Marais-Steinman, 2003) have demonstrated that exposure to workplace mobbing can have serious noxious effects such as social isolation and maladjustment, psychosomatic illnesses, helplessness, anger, anxiety, and depression.

In a study reported by Einarsen and Mikkelsen (2003) three general reaction groups were identified. In the first group, vague physical symptoms like chronic fatigue, various aches and loss of strength were observed. The second group showed depressive signs such as insomnia, lack of self- esteem and indifference. The final group portrayed more severe psychological symptoms like irritability, hypersensitivity, hostility, memory problems, feelings of victimization and social withdrawal. As the frequency and number of aggressive behaviors increase, the effects on the individual become worse. Namie and Namie (2009) reported that $94 \%$ of the victims they had studied showed symptoms of anxiety disorder, $82 \%$ concentration problems, $76 \%$ obsessions and $41 \%$ depression problems. Moreover, sleep problems (Niedhammer et al., 2009; Hansen, et al., 2016) and tendency to use sleeping pills or tranquilizers in victims (Hogh, Mikkelsen \& Hansen, 2011) were stated. Soares (2012), identified hopelessness and even suicide ideation in victims.

Through negative thoughts and emotions, outcomes of mobbing do not harm the victims only, but also their families and relatives. Glomb (2002) and Rogers \& Kelloway (1997) mentioned the victimization of and negative outcomes on the third parties; families, relatives and colleagues. Duffy and Sperry (2007) stated that victims' families experienced the same feelings of humiliation and shame when the victim was unemployed or had difficulties at finding a new job.

Research generally implies that mobbing affects not only the victims but also the other employees, organizations and even the economics of the country. Hoel, Einarsen and Cooper (2003) demonstrated how mobbing victims become less productive, show less initiative, are less creative and make more mistakes. Decreased efficiency can be explained by the negative effects of mobbing process on victim's job satisfaction, motivation and attachment. In addition, perceived stress also negatively affects productivity, while social isolation and lack of community prevents the victim from accessing necessary information to be productive. Third parties are also affected in terms of productivity. Victim's communication about their experience and related rumors in the organization increase the general stress level in employees (Vartia, 2001). In a study reported by Hauge et al. (2007) while victims complained about low job satisfaction and high levels of workplace stress, witnesses showed the same symptoms, however in lower quantities.

Beyond direct effects on work life, mobbing also causes indirect socio-economic harm: costs related to medical treatment and psychological counseling, sick leave salaries, compensation costs via dismissals, and loss of labor after work accidents are all phenomena that attest to these effects (Grebot, 2007). Research has demonstrated the correlation between mobbing and turnover intention. In some cases, leaving may seem the best solution since it eliminates the source of the problem. For some others, it may be inevitable because of long term health problems (Hoel et al., 2003). Turnover due to mobbing leads to important socio-economic problems. Employees who quit their jobs may not get employed immediately, and this lack of qualified workforce is a loss for the economy (Grebot, 2007).

\section{Mobbing Studies in Turkey}

In general, mobbing studies are mainly conducted in education and health sectors in Turkey. For example; Yildız (2007), found that prevalence of mobbing was $47 \%$ in health and education sectors. Bilgel, Aytaç and Bayram (2006) determined a higher percentage (55\%) with 877 participants from education, health and security sectors. In another study (Yildırım and Yıldırım, 2007) with a total of 505 nurses from public and private sectors reported an extreme percentage; $85 \%$ of being exposed to mobbing. Tengilimoğlu, Akdemir-Mansur \& Dziegielewski, (2010) determined $78 \%$ prevalence with health staff. In a similar study with nurses and midwives (Güven, Özcan and Kartal, 2012), it was found that $12.7 \%$ of the participants were exposed to aggressive behaviors at least once in the last six months.

In the education sector elementary and junior high school researches, the percentages were similar; Cemaloğlu (2007) 50\%, and Cemaloğlu and Ertürk (2007) 85\%. However, higher education studies showed lesser rates. Seçkin-Çelik (2013), for example, surveyed the education sector with 481 university lecturers and determined $26 \%$ mobbing victims. Kontaş-Çevik (2011) found a similar percentage (29\%) with 601 university lecturers. 
There were even lesser percentages in the studies of Yelçelen-Tigrel and Kökalan (2009) and Tanoğlu, Aricioglu and Kocabas (2007) 11,6\% and 15,8\% respectively.

One of the most prevalent mobbing sector is finance (Davenport, Schwartz, \& Elliot, 2002). In one of these finance sector studies; Yılmaz and Uzunçarşili- Soydaş (2006) determined 15\% frequency. Gök (2011), in a research in banking sector concluded that $32 \%$ of the participants were exposed to mobbing at least once lifetime and 16\% were exposed last year. Idig-Camuroglu and Minibas-Poussard (2015) found a similar rate, $30 \%$, with bank workers. To see different percentages of prevalence even in the same sector might be confusing. However, a plausible explanation for this difference could be the different methodologies of the studies.

\section{Purpose of the Study}

Until recently, there has not been wide-range of data on mobbing in Turkey. There is a need to acquire the prevalence rates and profiles of mobbing in different sectors. In this context, the present study aims to contribute to this developing body of research by investigating mobbing in different sectors besides with exploring the relationship between work environment perception and mobbing in Turkey.

\section{METHODOLOGY}

\section{Sample and Data Collection}

Data collection was carried out in 10 cities - Istanbul, Ankara, İzmir and 7 other cities of each region of Turkey. The size of sample collected from each city is close to the proportion of the total population of the city's population. Participants who volunteered to contribute to this study by responding to the questionnaire were assured of the confidentiality of their responses. Questionnaires were delivered in the morning and collected back at the end of the very same day. Each questionnaire was placed in an envelope so that confidentiality would be assured.

Of 1200 surveys delivered, 853 of them were returned $(\mathrm{N}=853)$. The participants aged between 21 and 51 (49\% was $21-30,30 \%$ was $31-40,14 \%$ was $41-50$ and $7 \%$ was 51 years old), $45 \%$ were female. Of the sample, $50 \%$ was high school, $41 \%$ was university graduates, and only $9 \%$ had M.A. or Ph.D. degree. For the marital status, $43 \%$ was single, $50 \%$ married and $7 \%$ was divorced or widowed. The sample was composed of participants selected across the organizational hierarchy (50\% clerical workers, $25 \%$ experts, $15 \%$ supervisors and $10 \%$ managers) from private $(67 \%)$ and public $(33 \%)$ sectors which are health (12\%), education $(13 \%)$, banking/finance $(10 \%)$, auditing $(8 \%)$, IT $(8 \%)$, tourism $(9 \%)$, transportation $(8 \%)$ and marketing/sales $(13 \%)$, state institutions (13\%). In terms of experience; $22 \%$ had $0-1$ year, $30 \%$ had $1-3$ years, $15 \%$ had $3-5$ years and $33 \%$ had 5 years and more.

\section{Measures}

All translated instruments were back-translated to control for the quality of the national version by independent bilingual individuals. The scales showed satisfactory psychometric properties. All instruments were rated on a scale ranging from 1 to 5 .

i. Mobbing Scale: Developed by the authors, the scale is inspired from the instruments developed by Leymann (1996a) and Neuman and Keashly (2004). The scale aims to evaluate the nature and severity of mobbing and is composed of 30 items (Cronbach's $\alpha=0.94$ ).

ii. Workplace Evaluation: A 5-point scale of 16 items was used such as stress, conflict, work overload, oppressing management, injustice and ambiguity (Cronbach's $\alpha=0.93$ ).

\section{RESULTS}

\section{General Evaluation of Aggressive Behaviors and Mobbing Rate}

The aggressive behaviors experienced over the period of 12 months and their frequencies are presented in Table 1. Results showed that according to Leymann's (1996a) categorization, the most frequent aggressive behaviors were threats to the victim's personal and occupational reputation. Frequent behaviors included having been denied a praise or promotion, having had one's contributions ignored by others, having been given unreasonable workloads above competence or simple and meaningless work below competence, having been subjected to unjust evaluation, having been blamed for other people's mistakes, having had others continuously oppose one's ideas and decisions, having had others prevent necessary information from one, having had someone else take credit for one's ideas or success, not having been given any assignments or having had others prevent one from getting any assignments. Although most of these aggressive behaviors are in the category of threats to victim's personal reputation (Leymann, 1996a) they, nevertheless, are related to work as well. The other aggressive behaviors which threaten victim's personal reputation are; having been subjected to bad jokes and having been subjected to rumors. Moreover, behaviors like having been prevented from expressing oneself, having been 
interrupted when speaking, not been listened to and having been excluded in work environment can be counted as the most frequent behaviors.

TABLE 1

Percentages of Self-Report Experienced Aggressive Behaviors Per Year

\begin{tabular}{|c|c|c|c|c|}
\hline Aggressive Behaviors & a year & $\begin{array}{l}\text { A few } \\
\text { times a } \\
\text { month }\end{array}$ & $\begin{array}{c}\text { A few } \\
\text { times a } \\
\text { week }\end{array}$ & $\begin{array}{l}\text { Almost } \\
\text { eryday }\end{array}$ \\
\hline Been subjected to bad jokes & 25 & 10.2 & 6.4 & 7.5 \\
\hline Been excluded in work environment & 15 & 10.3 & 9.5 & 5.2 \\
\hline $\begin{array}{l}\text { Been prevented from expressing yourself, interrupted when speaking, not been } \\
\text { listened to }\end{array}$ & 21 & 10.8 & 9.8 & 7.5 \\
\hline Had others prevented from talking to you & 13 & 6.6 & 6.7 & 2.6 \\
\hline Been disturbed verbally, written or by phone calls & 12 & 7.8 & 5.7 & 3 \\
\hline Been subjected to excessive criticism about your work & 23 & 13.8 & 8.5 & 5 \\
\hline Been subjected to rumors & 20 & 10.3 & 7.7 & 6.5 \\
\hline Been criticized for personal life and activities & 11 & 8.1 & 4 & 5.4 \\
\hline Been blamed for other people's mistakes & 21 & 14.2 & 9 & 5.9 \\
\hline Had others prevent necessary info from you & 15 & 10.5 & 9.5 & 5.5 \\
\hline $\begin{array}{l}\text { Not been given any assignments or had others prevent you getting any } \\
\text { assignments }\end{array}$ & 14.6 & 10.3 & 8.1 & 6.1 \\
\hline Been given unnecessary workloads below competence & 16.5 & 11.5 & 9.3 & 9.6 \\
\hline Been given unreasonable workloads above competence & 16.6 & 15 & 10 & 9.7 \\
\hline Been scorned about weaknesses & 7.6 & 7 & 4.7 & 1.5 \\
\hline Been subjected to unjust evaluation & 20.5 & 15 & 9.5 & 7.5 \\
\hline Been labeled as mentally sick & 5 & 3 & 3 & 1 \\
\hline Been sexually assaulted & 5.6 & 3.6 & 2.1 & 3.1 \\
\hline $\begin{array}{l}\text { Been threatened with physical harm (hitting, injuring, killing) or been physically } \\
\text { harmed }\end{array}$ & 8.5 & 3.5 & 3 & 2 \\
\hline Been subjected to futile effort & 10 & 6.8 & 3.5 & 3.2 \\
\hline Been yelled at or shouted at in a hostile manner & 13 & 5.7 & 5.5 & 3 \\
\hline Been subjected to humiliation about your political or religious beliefs & 10 & 10 & 8 & 4.5 \\
\hline Been denied a praise or promotion without being given a valid reason & 22.3 & 16.3 & 12 & 11 \\
\hline Had your belongings destroyed & 5.5 & 4.7 & 1.7 & 1.6 \\
\hline Had others fail to warn you about impending dangers & 7 & 10.7 & 8 & 4.7 \\
\hline Been rejected about help demand on purpose & 10 & 10.7 & 5 & 4.7 \\
\hline Had others delay action on matters important to you & 19.5 & 11.6 & 6 & 7.5 \\
\hline
\end{tabular}

According to the data, the thirty aggressive behaviors mentioned in Table 1 have a frequency ranging between $14 \%$ and $59 \%$. This does not necessarily mean that up to $59 \%$ of the participants are victims of mobbing. Using the definition of frequency (once or twice a week) of Leymann's work, the present data show exposure to mobbing at $23 \%$. Although being exposed to aggressive behaviors from time to time was $47 \%$, this result cannot be defined as mobbing (see Figure 1).

Furthermore, not all of the participants who had experienced mobbing perceived themselves as victims: only $17 \%$ of them stated that their lives had been ruined because of mobbing. This difference may be the result of the 
number of the measured aggressive behaviors. The number of aggressive behaviors modifies the intensity of mobbing. Participants who did not perceived themselves as victims had been exposed to less aggressive behaviors than the others. In the present data, the number of different aggressive behaviors rises up to $23 \%$ at least once or twice a week (see Figure 2).

FIGURE 1

Exposure and Frequency of Aggression

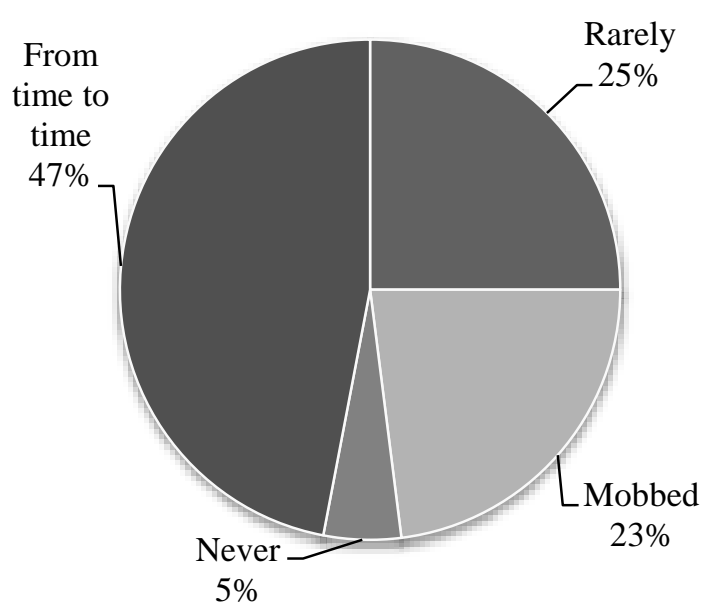

FIGURE 2

Number of Aggressive Behaviors Exposed to at Least Once or Twice a Week

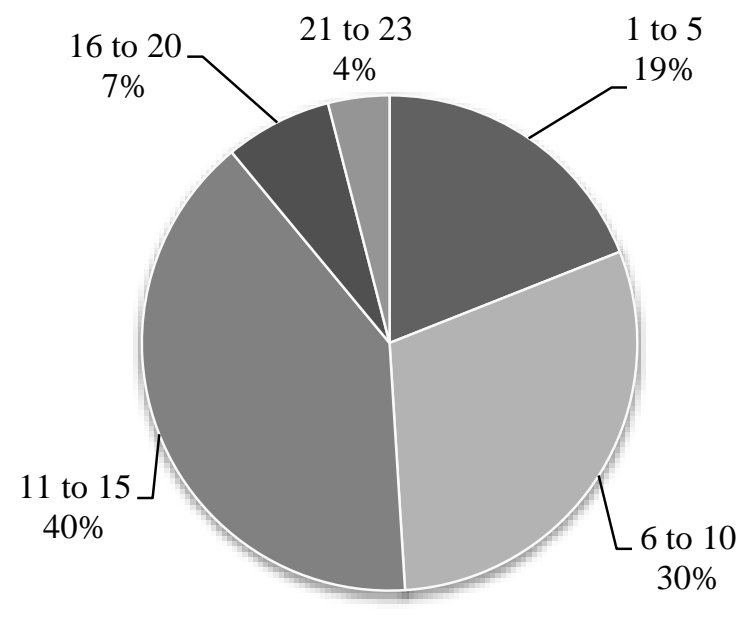

Those who were exposed to mobbing $(23 \%)$ have the following demographic profile:

Of the victims $58 \%$ are $21-30$, and $31 \%$ are $31-40$ years old. The ratio of men to women is $61 \%$, however, it is not statistically significant. Of the victims, $80 \%$ work in private sector. $60 \%$ work at middle and large size organizations. $25 \%$ work at marketing/import/export companies, $10 \%$ educational sector and $10 \%$ state institutions. Most of the victims are recently employed workers; $29 \%$ are $0-1$ year, $31 \%$ are in the company for 1-3 years, $58 \%$ of the victims are at the positions like civil servant, secretary and office workers.

Over $50 \%$ of the hostile behaviors in the category of threat to victim's occupational reputation (excessive criticism, blaming for other people's mistakes, workloads below or above competence, unjust evaluations, ignoring contributions) are perpetrated by superiors. Over $50 \%$ of the hostile behaviors in the category of threats to victims' communication and maintaining social contacts are perpetrated by superiors. On the other hand, more than $50 \%$ of the hostile behaviors threats to victim's personal reputation are committed by colleagues. Superiors and colleagues had a similar percentage on the dimension of having had someone else take credit for one's ideas or success.

\section{Mobbing and Work Environment}

In negative work environment context; stress, conflicts, excessive workloads, oppressive management, injustice and ambiguity were addressed. Correlation analyses indicate that negative work environment laid a fertile ground for mobbing (see table 2).

TABLE 2

Correlations between Work Environment Perception and Mobbing

\begin{tabular}{lllllll}
\hline & $\mathbf{1}$ & $\mathbf{2}$ & $\mathbf{3}$ & $\mathbf{4}$ & $\mathbf{5}$ & $\mathbf{6}$ \\
\hline 1. Level of mobbing & & & & & & \\
2. Stressful work environment & $.17^{*}$ & & & & & \\
3. Conflicts in work environment & $.25^{* *}$ & $.45^{* *}$ & & & & \\
4. Excessive workload & $.20^{* *}$ & $.46^{* *}$ & $.39^{*}$ & & & \\
5. Oppressive management & $.35^{* *}$ & $.38^{* *}$ & $.52^{* *}$ & $.43^{* *}$ & & $.65^{* *}$ \\
6. Injustice in work environment & $.28^{* *}$ & $.28^{* *}$ & $.38^{* *}$ & $.35^{* *}$ & $.63^{* *}$ & $.60^{* *}$ \\
7. Ambiguity in work environment & $.23^{* *}$ & $.30^{* *}$ & $.39^{* *}$ & $.36^{* *}$ & $.47^{* *}$
\end{tabular}

According to correlation analyses; they all lead up to mobbing, however, multiple regression analyses revealed that oppressive management was the most influential $\left(\mathrm{R}=0.38, \mathrm{R}^{2}=0.15, \mathrm{~F}=22.68, \beta=0.23, \mathrm{p} \leq 0.001\right)$. 


\section{DISCUSSION AND CONCLUSION OF THE STUDY}

In this cross-sectional national study, we aimed to determine the prevalence of mobbing behavior. Given that different criteria for mobbing have been applied in previous studies, the comparison between our data with the existing knowledge about the phenomenon is somehow complicated. In research findings using similar criteria, mobbing rate is 3.5\% in Sweden (Leymann, 1996a), 11\% in UK (Hoel et al., 2001) and 7.6\% in Switzerland (Künzi et al., 2006) while it is $23 \%$ in Turkey. It is important to note that lower levels of mobbing in European countries may be due to longer history of research and legislations to prevent bullying behavior. Furthermore, the number of self-reported hostile behaviors that our participants were exposed to is higher than that reported elsewhere. For instance, in Keashly and Neuman's (2002) research, the number of aggressive behaviors was reported to range from 1 to 5 and above 6+; whereas this number is 23 in our study.

In general, the most frequent hostile behaviors that participants reported were threats to the victim's personal and occupational reputation, being denied praise or promotion, having one's contributions ignored by others, been given unreasonable workloads above one's competence or simple and meaningless work below one's competence, and been subjected to unjust evaluation. The aggressive behaviors are similar with those obtained from other European countries such as Sweden (Leymann, 1996a), France (Hirigoyen, 2001), the UK (Hoel et al., 2001), Finland (Salin, 2001; Vartia, 2001), Bosnia (Pranjic, Bilic, Beganic \& Mustajbegovic, 2006) as well as other studies conducted in Turkey (Bilgel et al., 2006; Yıldız, 2007; Cemaloğlu, 2007). The similarity in aggressive behaviors obtained from such different cultures and work environments is worth considering for further discussion.

The present data reveal that perpetrators of mobbing behaviors are mostly superiors (between $49 \%$ and $68 \%$ ), similar to the findings of most of other studies (Leymann, 1996a; Hoel et al., 2001; Marais-Steinman, 2003; Künzi et al., 2006; Spector, Coulter, Stockwell \& Mat, 2007). Moreover, the data of our study support previous findings that the most powerful factor for mobbing behaviors at the workplace is oppressive management. In terms of gender, males reported higher percentages of having been the subject of mobbing. Being young and recently employed and at a lower hierarchical position means being at risk. Beyond the public sector, risk sectors include marketing, export/import and education. Work environment also play an important role in mobbing. According to Einarsen, Raknes \& Matthiesen (1994), mobbing correlate with several aspects of organizational and social work environment such as excessive work-loads, competition, leadership, social climate, role ambiguity and conflict. Our results also supported this relationship.

As a universal phenomenon, mobbing is an important psychological, social and economic problem in almost every culture. Yet the situation in our country has not been examined thoroughly, the reality is not fully clear. Nevertheless, based on the limited existing data we can claim that compared to some European countries, mobbing rate in Turkey is unpromising. Since mobbing is not a simple problem between the perpetrator and victim, it affects co-workers and the productivity besides with families. In order to develop effective preventions we need more qualitative and quantitative research.

\section{REFERENCES}

1. Aquino, K., Grover, S. L., Bradfield, M., \& Allen, D.G. (1999). The effects of negative affectivity, hierarchical status, and self-determination on workplace victimization. Academy of Management Journal, 42, 260-272.

2. Baron, R.A. \& Neuman, J.H. (1996). Workplace violence and workplace aggression: evidence on their relative frequency and potential causes. Aggressive Behavior, 22, 161-173.

3. Baron, R.A. \& Neuman, J.H. (1998). Workplace aggression- the iceberg beneath the tip of workplace violence: Evidence on its forms, frequency and target. Public Administration Quarterly, 21, 161-173.

4. Baron, R. A., Neuman, J. H., \& Geddes, D. (1999). Social and personal determinants of workplace aggression: Evidence for the impact of perceived injustice and the Type A behavior pattern. Aggressive Behavior, 25(4), 281-296.

5. Bilgel, N., Aytac, S., \& Bayram, N. (2006). Bullying in Turkish white-collar workers. Occupational Medicine, 56, 226-231.

6. Bjorkqvist, K., Osterman, K., \& Lagerspetz, K. M. (1994). Sex differences in covert aggression among adults. Aggressive Behavior, 20(1), 27-33.

7. Bréard, R., \& Pastor, P. (2002). Harcèlements: les réponses. Paris: Editions Liaisons.

8. Bronfenbrenner, U. (1979). The ecology of human development: Experiments by nature and design. Cambridge, MA: Harvard University Press.

9. Brodsky, C.M. (1976). The Harassed Worker. Toronto: Lexington Books.

10. Buss, A.H. (1961). The Psychology of Aggression. New York: Wiley. 
11. Cemaloğlu, N. (2007). The exposure of Turkish primary school teachers to bullying: An analysis of various variables. Social Behavior and Personality, 35(6), 789-802.

12. Cemaloğlu, N. \& Ertürk, A. (2007). Öğretmenlerin maruz kaldıkları yıldırma eylemlerinin cinsiyet yönünden incelenmesi. Türk Egitim Bilimleri Dergisi, 5(2), 345-362.

13. Cortina, L.M., Magley, V.J., Williams, J.H., \& Langhout, R.D. (2001). Incivility in the workplace: Incidence and impact. Journal of Occupational Health Psychology, 6(1), 64-80.

14. Davenport, N., Schwartz, R.D., \& Elliot, G.P. (2002). Mobbing: Emotional Abuse in the American Workplace. Iowa: Civil Society Publishing.

15. Debout, M. \& Larose, C. (2003). Violence au travail. Paris: VO Editions.

16. Dermaret, A. (1979). Ethologie et Psychiatrie. Bruxelles: Mardaga.

17. Duffy, M., \& Sperry, L. (2007). Workplace mobbing: Individual and family health consequences. The Family Journal, 15, 4, 398-414.

18. Einarsen, S. (1999). The nature and causes of bullying at work. International Journal of Manpower, 20 ( $1 / 2), 16-27$.

19. Einarsen, S., Raknes, B.I., \& Matthiesen, S.B. (1994). Bullying and harassment at work and their relationship to work environment quality: An exploratory study. European Work and Organizational Psychologist, 4(4), 381-401.

20. Einarsen, S., \& Mikkelsen, E.G. (2003). Individual effects of exposure to bullying at work. In S. Einarsen et al. (Eds). Bullying and Emotional Abuse in the Workplace. International Perspectives in Research and Practice (pp. 127-144). London: Taylor and Francis.

21. Gillow, E., Hopkins, M., \& Williams, A. (2003). Harrasment at work. Bristol: Jordan Publishing.

22. Einarsen, S., Hoel. H., \& Notelaers, G. (2009). Measuring exposure to bullying and harassment at work: Validity, factor structure and psychometric properties of the Negative Acts Questionnaire-Revised. Work and Stress, 23(1), 24-44.

23. Glomb, T. M. (2002). Workplace anger and aggression: Informing conceptual models with data from specific encounters. Journal of Occupational Health Psychology, 7, 20-36.

24. Gök, S. (2011). Prevalence and types of mobbing behavior: A research on banking sector. International Journal of Human Sciences, 8, 1, 318-334.

25. Grébot, E. (2007). Harcèlement au Travail. Paris: Editions d'Organisation.

26. Güven, S., Özcan, A., \& Kartal, B. (2012). Nevşehir il merkezinde kamuya bağlı sağlık kuruluşlarında çalışan ebe ve hemşirelerin mobbinge uğrama durumları. Balıkesir Sağlık Bilimleri Dergisi, 1(3), 117-123.

27. Hansen, Å.M., Gullander, M., Hogh, A., Persson, R., Kolstad, H.A., Willert, M.V., Bonde, J.P., Kaerlev, L., Rugulies, R., Grynderup, M.B. (2016). Workplace bullying, sleep problems and leisure-time physical activity: a prospective cohort study. Scandinavian Journal of Work, Environment and Health, 42(1), 26-33.

28. Hauge, L.J., Skogstad, A., \& Einarsen, S. (2007). Relationship between stressful work environments and bullying: Results of a large representative study. Work and Stress, 21 (3), 220-242.

29. Hirigoyen, M-F. (2001). Le harcèlement moral dans la vie professionnelle. Paris: Syros.

30. Hoel, H. \& Cooper, C.L. (2001). Origins of bullying. In N. Tehrani (Ed). Building a Culture of Respect Managing Bullying at Work (pp. 3-21). London: Taylor Francis. (pp. 3-21).

31. Hoel, H., Cooper, C.L., \& Faragher, B. (2001). The experience of bullying in Great Britain: The impact of organizational status. European Journal of Work and Organizational Psychology, 10(4). 443-464.

32. Hoel, H., Einarsen, S., \& Cooper, C.L. (2003). Organizational effects of bullying. In S. Einarsen et al. (Eds). Bullying and Emotional Abuse in the Workplace, International Perspectives in Research and Practice (pp.145-162). London: Taylor and Francis.

33. Hofsteade, G. \& Bollinger, D. (1987). Les différences culturelles dans le management. Paris: Editions d'Organisation.

34. Hogh, A., Mikkelsen, E.G., \& Hansen, A.M. (2011). Individual consequences of workplace bullying/mobbing. In S. Einarsen et al. (Eds). Bullying and Emotional Abuse in the Workplace, International Perspectives in Research and Practice, Second Edition (107-125). London: Taylor and Francis.

35. Idig-Camuroglu, M. \& Minibas-Poussard, J. (2015). Mobbing at banks: Moderating effect of negative emotions on the relationship between mobbing and turnover intention. AJBMR, 5, 2, 14-24.

36. Johnson, S.L. (2011). An Ecological model of workplace bullying: A Guide for intervention and research. Nursing Forum, 46, 55-63.

37. Keashly, L. (1998). Emotional abuse in the workplace: Conceptual and empirical issues. Journal of Emotional Abuse, 1(1), 85-117.

38. Keashly, L. \& Neuman, J. H. (2002). Exploring persistent patterns of workplace aggression. Workplace abuse, aggression, bullying, and incivility: Conceptual and empirical insights. Symposium conducted at the meeting of the Academy of Management, Denver, CO. 
39. Kernberg, O. (2002). Contribution from North America (2): The couch at sea. In R.D. Hinselwood \& M. Chiesa (Eds). Organizations, Anxieties \& Defenses: Towards a Psychoanalytic Social Psychology (pp. 6576). London: Whurr Publishers.

40. Kivimaki, M., Elovainio, M., \& Vahtera, J. (2000). Workplace bullying and sickness absence in hospital staff. Journal of Occupational and Environmental Medicine, 57, 656-660.

41. Kontaş-Çevik, S. (2011). Üniversitelerde Öğretim Elemanlarinin Yildirma (Mobbing) Davranişlarina Maruz Kalma Düzeyi Yayınlanmamış yüksek lisans tezi, Hacettepe Üniversitesi, Eğitim Bilimleri ABD, Ankara.

42. Künzi, G., Vicario, A., Künzi, D. \& Jeandet, C. (2006). Harcèlement sur le lieu de travail. Lausanne: Presses Polytechniques et Universitaire Romandes.

43. Legeron, P. (2000). Stress au travail. Paris: Editions Odile Jacob.

44. Leymann, H. (1996a). La persécution au travail. Paris: Editions du Seuil.

45. Leymann, H. (1996b). The content and development of mobbing at work. European Journal of Work and Organizational Psychology, 5(2), 165-184.

46. Leymann, H. \& Gustafsson, A. (1996). Mobbing at work and the development of post traumatic stress disorder. European Journal of Work and Organizational Psychology, 5(2), 251-275.

47. Lutgen-Sandvik, P., Tracy, S.J., \& Alberts, J.K. (2007). Burned by bullying in American workplace: Prevalence, perception, degree and impact. Journal of Management Studies, 44(6), 837-863.

48. Marais-Steinman, S. (2003). Challenging workplace bullying in a developing country: the example of South Africa. In S. Einarsen et al. (Eds). Bullying and emotional abuse in the workplace. international perspectives in research and practice (pp. 312-324). London: Taylor and Francis.

49. Mathieu, C., Neumann, C. S., Hare, R. D., \& Babiak, P. (2013). A dark side of leadership: Corporate psychopathy and its influence on employee well-being and job satisfaction. Personality and Individual Differences, 59, 83-88.

50. Mikkelsen, E.G. \& Einarsen, S. (2001). Bullying in Danish work life: Prevalence and health correlates. European Journal of Work and Organizational Psychology, 10, 393-413.

51. Namie, G. \& Namie, R. (2009). The bully at work; what you can do to stop the hurt and reclaim your dignity on the job. Naperville: Sourcebooks.

52. Neuman, J.H., \& Baron, R.A. (1998). Workplace violence and workplace aggression: Evidence concerning specific forms, potential causes, and preferred targets. Journal of Management, 24, (3), 391-419.

53. Neuman, J.H. \& Keashly, L. (2004). Development of workplace aggression research questionnaire (war-q): Preliminary data from workplace stress and aggression project. In R.J. Bennet \& C.D. Crossley, Theoretical Advancements in the Study of Antisocial Behavior and Work. Symposium conducted at the meeting of Society for Industrial and Organizational Psychology. Chicago, IL.

54. Niedhammer, I., David, S., Degioanni, S., Drummond, A., \& Philip, P. (2009). Workplace bullying and sleep disturbances: Findings from a large scale cross-sectional survey in the French working population. Sleep, 32(9), 1211-1219.

55. O’Moore, M., Seigne, E., McGuire, L., \& Smith, M. (1998). Victims of bullying at work in Ireland. Journal of Occupational Health and Safety: Australia and New Zealand, 14(6), 568-574.

56. Pranjic, N., Bilic, L.M., Beganic, A., \& Mustajbegovic, J. (2006). Mobbing, stress and work ability index among physicians in Bosnia and Herzegovina: survey study. Croatian Medical Journey, 47, 750-758.

57. Rayner, C., Hoel, H., \& Cooper, C.L. (2002). Workplace bullying: what we know. who is to blame. and what can we do? London: Taylor \& Francis.

58. Rogers, K. \& Kelloway, E. K. (1997). Violence at work: Personal and organizational outcomes. Journal of Occupational Health Psychology, 2, 63-71.

59. Salin, D. (2001). Prevalence and forms of bullying among business professionals: A comparison of two different strategies for measuring bullying. European Journal of Work and Organizational Psychology, 10(4), 425-441.

60. Seçkin-Çelik, T. (2013). Psikolojik Taciz: Öğretim Elemanlarına Yönelik Bir Araştırma, Yayınlanmamış yüksek lisans tezi, Galatasaray Üniversitesi, İşletme ABD. İstanbul.

61. Soares, A. (2012). When darkness comes; workplace bullying and suicidal ideation. Workplace Bullying: Symptoms and Solutions, N. Tehrani (Ed.) London: Routledge, 67-80.

62. Spector, P. E., Coulter, M.L., Stockwell, H. G., \& Mat, M.W. (2007). Perceived violence climate: A new construct and its relationship to workplace physical violence and verbal aggression and their potential consequences. Work and Stress, 21(2), 117-130.

63. Spindel, P. (2008). Psychological Warfare at Work. Spindel \& Associates Inc.

64. Tanoğlu, S. C., Aricioglu, M. A., \& Kocabas, M. (2007). Research on Mobbing in Organizations: A Case Study on Academicians. Proceedings of the 37th International Conference on Computers and Industrial Engineering, 558-568. 
65. Tengilimoglu, D., Akdemir-Mansur, F., \& Dziegielewski, S.F. (2010). The Effect of the Mobbing on Organizational Commitment in the Hospital Setting: A Field Study. Journal of Social Service Research, 36 (2), 128-141.

66. Vartia, M. (1996). The sources of bullying-psychological work environment and organizational climate. European Journal of Work and Organizational Psychology, 5, 203-214.

67. Vartia, M. (2001). Consequences of workplace bullying with respect to well-being of its targets and the observers of bullying. Scandinavian Journal of Work, Environment and Health, 27, 63-69.

68. Wilson, C. B. (1991). U.S. businesses suffer from workplace trauma. Personnel Journal, 70(7), 47-50.

69. Wyatt, J. \& Hare, C. (1997). Work abuse: how to recognize and survive it. Vermont: Schenkman Books.

70. Yelgeçen-Tigrel, E. \& Kökalan, Ö. (2009). Academic mobbing in Turkey. International Journal of Social, Management, Economics and Business Engineering, 3(7), 272-280.

71. Yildırım, A. \& Yildırım, D. (2007). Mobbing in the workplace by peers and managers: mobbing experienced by nurses working in healthcare facilities in Turkey and its effect on nurses. Journal of Clinical Nursing, 16, (8), 1444-1453.

72. Yildiz, S. (2007). A new problem in the workplace: psychological abuse (bullying). Journal of Academic Researches, 34, 113-128.

73. Yılmaz, G. \& Uzunçarşıl1-Soydaş, A. (2006). Bullying Among Turkish Bank Employees and Its Relation with Sick Leave, Proceedings of Asia Pacific Management Conference, 1-4.

74. Zapf, D., Knorz, C., \& Kulla, M. (1996). On the relationship between mobbing factors and job content. social work environment and health outcomes. European Journal of Work and Organizational Psychology, $5,(2), 215-237$.

75. Zapf, D. (1999). Organizational. work group related and personal causes of mobbing / bullying at work. International Journal of ManPower, 201/2, 70-85.

76. Zapf, D. \& Einarsen, S. (2003). Individual antecedents of bullying: victims and perpetrators. In S. Einarsen et al. (Eds). Bullying and Emotional Abuse in the Workplace. International Perspectives in Research and Practice (pp. 165-185). London: Taylor and Francis. 